\title{
Hubungan Kepadatan dan dengan Luas Permukiman terhadap Sebaran Demam Berdarah Dengue
}

\section{The Relationship between Density and Area of Residential to the Distribution of Dengue Hemorrhagic Fever}

\author{
Marlena $^{1}$, Rinidar $^{2}$, Muhammad Rusdi $^{3}$, Farida $^{4}$, Teuku Reza Ferasyi ${ }^{5}$ Nurliana $^{6}$ \\ ${ }^{1}$ Fakultas Kedokteran Hewan, Universitas Syiah Kuala, Banda Aceh, Aceh \\ ${ }^{2}$ Laboratorium Farmakologi, Fakultas Kedokteran Hewan, Universitas Syiah Kuala, Banda Aceh Aceh \\ ${ }^{3}$ Laboratorium Penginderaan Jauh dan Kartografi, Fakultas Pertanian Universitas Syiah Kuala \\ Banda Aceh, Aceh \\ ${ }^{4}$ Laboratorium Parasitologi, Fakultas Kedokteran Hewan, Universitas Syiah Kuala, Banda Aceh, Aceh \\ ${ }^{5}$ Laboratorium Kesehatan Masyarakat Veteriner, Fakultas Kedokteran Hewan, Universitas Syiah Kuala, \\ Banda Aceh, Aceh \\ ${ }^{6}$ Laboratorium Kesehatan Masyarakat Veteriner, Fakultas Kedokteran Hewan, Universitas Syiah Kuala, \\ Banda Aceh, Aceh \\ Email: lena_kkp@yahoo.co.id
}

Naskah diterima: 17 Juli 2019, direvisi: 30 Juli 2019, disetujui: 11 April 2020

\begin{abstract}
Banda aceh which part of the area is a coastal area and lowland, is an endemic area of dengue hemorrhagic fever (DHF). The case of DHF in Banda Aceh is always fluctuating from year to year so it needs to be analyzed the relationship of the environment to the distribution of DHF. The purpose of this study was to analyze the relationship between settlement density and settlement area to the distribution of DHF in Banda Aceh City. This research uses visual interpretation and overlay methods using quantitative descriptive research design. Descriptive research was conducted using a survey method based on a cross-sectional study. The survey was carried out on the density of settlements and was associated with the incidence of DHF spatially. The type of data used is primary data obtained through direct observation using the Global Positioning System (GPS) to see the distribution of DHF and interpretation data of remote sensing images to see patterns of settlement density. While secondary data from the Banda Aceh City Public Works and Spatial Planning Office and the Banda Aceh City Health Office. The number of samples was all DHF sufferers in 2017 totaling 236 people spread in the city of Banda Aceh. Data were analyzed using ArcGIS and processed statistically using Chi-Square. Sparse residential density areas of $46.7 \%$ have 3 points of high category DHF cases, areas of medium settlement density of $34.4 \%$ have 7 points of high category DBD cases and areas of densely populated densities of $18.9 \%$ have 5 points of high category DBD cases. Statistical test results showed a value of $\mathrm{P}>0.05$, meaning that there was no relationship between settlement density and the incidence of dengue cases in Banda Aceh City. There is no relationship between the density of settlements with the area of settlements to the distribution of dengue hemorrhagic fever (DHF) in the city of Banda Aceh.
\end{abstract}

Key words: Aedes aegypty; case DHF; Geographic Information System; settlement density 


\begin{abstract}
Abstrak
Kota Banda Aceh merupakan daerah endemis penyakit Demam Berdarah Dengue (DBD). Kasus DBD di Banda Aceh selalu fluktuatif dari tahun ke tahun sehingga perlu dianalisis hubungan lingkungan terhadap sebaran DBD. Tujuan dari penelitian ini adalah untuk menganalisis hubungan kepadatan permukiman dengan luas permukiman terhadap sebaran DBD di Kota Banda Aceh. Penelitian ini menggunakan metode interpretasi visual dan overlay dengan menggunakan rancangan penelitian deskriptif kuantitatif. Penelitian deskriptif dilakukan dengan metode survei berdasarkan studi cross-sectional. Survei dilakukan terhadap kepadatan permukinan dan dikaitkan dengan kejadian DBD secara spasial. Jenis data yang digunakan adalah data primer diperoleh melalui observasi langsung menggunakan alat Global Positioning System (GPS) untuk melihat sebaran DBD dan data interpretasi citra penginderaan jauh untuk melihat pola kepadatan permukiman. Sedangkan data skunder dari Dinas Pekerjaan Umum dan Penataan Ruang Kota Banda Aceh dan Dinas Kesehatan Kota Banda Aceh. Jumlah sampel adalah seluruh penderita DBD tahun 2017 berjumlah 236 orang yang tersebar di Kota Banda Aceh. Data di analisis menggunakan ArcGIS dan diolah secara statistik menggunakan Chi-Square. Daerah kepadatan permukiman jarang sebesar 46,7\% memiliki 3 titik kasus DBD katagori tinggi, daerah kepadatan permukiman sedang sebesar 34,4\% memiliki 7 titik kasus DBD katagori tinggi dan daerah kepadatan permukiman padat sebesar 18.9\% memiliki 5 titik kasus DBD kategori tinggi. Hasil uji statistik memperlihatkan nilai $\mathrm{P}>0,05$, artinya tidak ada hubungan kepadatan permukiman dengan kejadian kasus DBD di Kota Banda Aceh.Tidak terdapat hubungan kepadatan permukiman dengan luas permukiman terhadap sebaran demam berdarah dengue (DBD) di Kota Banda Aceh.
\end{abstract}

Kata kunci : Aedes aegypty; kasus DBD; kepadatan permukiman; sistem informasi geografis

\section{Pendahuluan}

Demam berdarah dengue (DBD) adalah penyakit yang banyak ditemukan di sebagian besar wilayah tropis dan subtropis dan merupakan masalah kesehatan masyarakat dunia (WHO, 2012). Hostalami DBD adalah manusia, agentnya adalah virus dengue yang termasuk kedalam family Flaviridae dan genus Flavivirus, terdiri dari 4 serotipe yaitu Denv-1, Denv-2, Denv3 dan Denv-4, ditularkan ke manusia melalui gigitan nyamuk yang terinfeksi, khususnya nyamuk Aedes aegypti dan Aedes albopictus (Chandra, 2010). Penyebaran DBD sangat cepat meningkat sejak 30 tahun terakhir. Pada tahun 1970, hanya sembilan negara yang melaporkan kasus demam berdarah. Namum saat ini, diperkirakan 100 negara yang memiliki iklim tropis dan subtropis merupakan daerah endemis DBD. Diperhitungkan lebih dari $40 \%$ dari populasi dunia beresiko terkena virus dengue dan $87 \%$ dari total populasi di Asia Tenggara beresiko demam berdarah (WHO, 2009).

Di Indonesia penyakit DBD sejak tahun 1968 telah terjadi peningkatan persebaran kasus DBD. Pada tahun 1968 hanya 58 kasus menjadi 158.912 kasus pada tahun 2009. World Health Organization (WHO menetapkan Indonesia sebagai salah satu negara hiperendemik dengan jumlah provinsi yang terkena DBD sebanyak 32 provinsi dari 33 provinsi di Indonesia dan 355 kabupaten/kota dari 444 kota terkena DBD. Setiap hari dilaporkan, sebanyak 380 kasus DBD dan 1-2 orang meninggal setiap hari (WHO, 2009). Penyakit ini pertama kali dilaporkan terjadi di Surabaya. Selama tahun 1996-2005 tercatat 334.685 kasus DB dengan jumlah penderita yang meninggal 3.092 orang (Widyawati et al., 2011).

Kasus DBD di Indonesia pada tahun 2017 berjumlah 68.407 kasus, dengan jumlah kematian sebanyak 493 orang. Jumlah tersebut menurun cukup drastis dari tahun sebelumnya, yaitu 204.171 kasus dan jumlah kematian sebanyak 1.598 orang. Angka kesakitan DBD tahun 2017 menurun dibandingkan tahun 2016, yaitu dari 78,85 menjadi 26,10 per 100.000 penduduk. Namun, penurunan Case fatality rate (CFR) dari tahun sebelumnya tidak terlalu tinggi, yaitu $0,78 \%$ pada tahun 2016, menjadi 0,72\% pada tahun 2017 . Berikut tren angka kesakitan DBD selama kurun waktu 2010-2017 (Kemkes, 2018).

Berdasarkan laporan Dinas Kesehatan Kota Banda Aceh, Jumlah warga yang terjangkit DBD tahun 2012 sebanyak 506 kasus, tahun 2013 
sebanyak 258 kasus, tahun 2014 sebanyak 299 kasus, tahun 2015 sebanyak 127 kasus dan tahun 2016 sebanyak 152 kasus (Dinkes Banda Aceh, 2017). Pada tahun 2017 terdapat sebanyak 236 kasus DBD tersebar dalam sembilan kecamatan dengan IR (Incidence Rate) per 100.000 penduduk sebesar 59,6 (Dinkes Banda Aceh. 2018).

Jumlah kasus penyakit DBD cenderung meningkat sepanjang tahun, peningkatan ini terjadi karena adanya pembukaan lahan untuk pemukiman baru yang menambah jumlah habitat nyamuk (Kemkes, 2012). Penggunaan lahan yang di alih fungsikan menjadi pemukiman penduduk baik sementara maupun tidak menjadi salah satu faktor penyebab penyebaran penyakit DBD di suatu wilayah. Dikarenakan adanya mobilitas penduduk yang kemungkinan membawa virus dengue dari satu tempat ke tempat lainnya (Hadinegoro dan Satari, 2004). Penyebaran DBD banyak dilaporkan di daerah-daerah perkotaan dan daerah dengan pengembangan pemukiman baru yang strategis (Prasetyo, 2012). Dimana dengan kondisi seperti ini populasi penduduk semakin padat dan menyebabkan kepadatan tempat tinggal pada daerah tersebut. Hal ini menyebabkan jarak terbang nyamuk menjadi lebih pendek sehingga penularan semakin mudah dan cepat sehingga menciptakan kondisi yang tepat untuk transmisi nyamuk. Pemukiman penduduk yang padat dengan tingkat mobilisasi yang tinggi merupakan salah satu tempat yang sangat potensial untuk terjadinya penularan DBD (Sujariyakul et.al., 2005).

Secara nasional DBD tergolong penyakit menular dan menjadi prioritas pembangunan nasional jangka panjang 2005-2025 (Koban, 2005). Oleh karena itu, pemerintah kota Banda Aceh terus berupaya menanggulangi wabah DBD, namun penanggulangan DBD di kota Banda Aceh belum secara signifikan menurunkan jumlah kasus DBD. Selama ini, sebaran kasus DBD hanya berdasarkan adanya laporan dari kunjungan masyarakat ke Puskesmas atau layanan kesehatan lainnya. Padahal Penyakit DBD dipengaruhi tiga elemen utama yaitu agent, host dan environment yang sangat dinamis. Agentnya adalah nyamuk, hostnya adalah manusia dan environment adalah lingkungan dimana adanya habitat yeng mendukung untuk pertumbuhan nyamuk. Kondisi nyamuk yang dinamis serta mobilitas penduduk yang tinggi, memerlukan suatu sistem untuk memetakan sehingga diketahui pola sebaran DBD yang dapat dijadikan sebagai prediksi awal untuk dipakai sebagai dasar dalam melakukan intervensi DBD.

Sistem Informasi Geografis (SIG) merupakan suatu sistem komputer berdasarkan geografis yang dapat digunakan untuk menganalisis data. Seiring dengan berkembangnya teknologi, SIG dapat dimanfaatkan di dunia kesehatan untuk memetakan sebaran DBD dan melihat keterkaitan faktor lingkungan yang menjadi risiko terjadinya DBD. Pemetaan sebaran dengan menggunakan SIG bertujuan untuk mendapatkan suatu informasi baru mengenai gambaran pemetaan suatu penyakit atau masalah kesehatan agar mudah untuk dianalisis (Sunaryo et al., 2014). SIG dalam bidang kesehatan digunakan untuk melakukan analisis spasial penyakit khususnya hubungan antara faktor agen, vektor, dan populasi dengan lingkungan geografisnya (Chang et al., 2009).

\section{Materi dan Metode}

Penelitian ini dilakukan di sembilan Kecamatan yang ada di Kota Banda Aceh. Pelaksanaan penelitian dilakukan selama tiga bulan yaitu bulan Agustus s.dOktober 2018. Subjek penelitian adalah lokasi tempat tinggal penderita demam berdarah dengue sejak Januari 2017 sampai dengan 31 Desember 2017. Bahan dan alat yang digunakan pada penelitian ini meliputi Global Positioning System (GPS), aplikasi ArcGIS, laporan kasus DBD tahun 2017 dan peta administrasi Kota Banda Aceh. Data yang digunakan dalam penelitian ini adalah data primer berupa titik kasus DBD dan kepadatan permukiman. Sedangkan data sekunder diperoleh dari Dinas Kesehatan Kota Banda Aceh berupa data jumlah penderita demam berdarah dengue tahun 2017 sebanyak 236 sampel dan data peta adminstrasi Kota Banda Aceh dari Dinas Pekerjaan Umum dan Penataan Ruang Kota Banda Aceh.

Data primer diperoleh melalui observasi langsung ke lokasi rumah penderita DBD menggunakan alat Global Positioning System (GPS) untuk melihat sebaran DBD dan data interpretasi citra penginderaan jauh untuk melihat kepadatan permukiman. Data tersebut kemudian 
dinputkedalamaplikasiArcGis. Klasifikasi sebaran kasus DBD dan kepadatan permukiman digunakan metode skoring. Pembuatan peta kepadatan permukiman dilakukan dengan pengambilan data dari citra penginderaan jauh. Kepadatan permukiman suatu desa dihitung berdasarkan jumlah luas seluruh atap dibagi dengan luas blok pemukiman dalam satuan unit pemukiman, sehingga dari hasil perhitungan tersebut dapat diketahui perbandingan antara penggunaan lahan pemukiman dan non pemukiman di desa tersebut (Dinas Cipta Karya PU, 2006).

Parameter yang digunakan dalam menilai kepadatan permukiman adalah berdasarkan Ditjen Cipta Karya Departemen Pekerjaan Umum tahun 2006. Dasar perhitungan Kepadatan permukiman adalah dengan menghitung persentase luas atap terhadap blok permukiman, besarnya nilai diklasifikasikan menggunakan metode skoring (Drobne dan Lisec, 2009). Kepadatan jarang dikenali dengan adanya halaman lebih luas dari luas bangunan. Keberadaan pohon lebih dominan dan jarak antar bangunan berjauhan. Kepadatan sedang dapat dilihat dari jarak antar rumah yang jarang, di antara bangunan rumah yang satu dengan rumah yang lainnya masih terdapat pohon yang merupakan halaman. Kepadatan padat dikenali dengan keberadaan bangunan yang saling berdekatan, dimana tiap bangunan relatif tidak memiliki halaman samping dan jika ada halaman lebih sempit dari pada luas bangunan (Kurniadi, 2014). Kepadatan permukiman diberi kategori sebagai berikut.

TABEL 1. Klasifikasi kepadatan permukiman

\begin{tabular}{lcc}
\hline \multicolumn{1}{c}{ Kriteria } & Klasifikasi & Skor \\
\hline $\begin{array}{l}\text { Kepadatan rumah rata-rata pada } \\
\text { pemukiman jarang }(\leq 40 \%)\end{array}$ & Jarang & 1 \\
\hline $\begin{array}{l}\text { Kepadatan rumah rata-rata pada } \\
\text { pemukiman sedang }(>41 \%-60 \%)\end{array}$ & Sedang & 2 \\
\hline $\begin{array}{l}\text { Kepadatan rumah rata-rata pada } \\
\text { pemukiman padat }(>60 \%)\end{array}$ & Padat & 3 \\
\hline
\end{tabular}

Sumber : Ditjen Cipta Karya PU tahun 2006 dengan modifikasi.

Data di analisis menggunakan ArcGIS melalui analisis buffer, skoring dan overlay. Data diolah secara statistik menggunakan Chi-Square.

\section{Hasil dan Pembahasan}

Kota Banda Aceh secara astronomi terletak antara $05^{\circ} 16^{\prime} 15^{\prime \prime}-05^{\circ} 36^{\prime} 16^{\prime \prime}$ Lintang Utara dan $95^{\circ} 16^{\prime} 15^{\prime \prime}-95^{\circ} 22^{\prime} 35^{\prime \prime}$ Bujur Timur dan berada di belahan bumi bagian utara dengan ketinggian wilayah kota berkisar antara $0,80 \mathrm{~m}-5,0 \mathrm{~m}$ di atas permukaan laut. Kota Banda Aceh memiliki 9 (sembilan) kecamatan dan 90 (sembilan puluh) desa dengan luas wilayah administratif adalah 61,36 km. Kota Banda Aceh memiliki posisi geografis dengan batas-batas sebagai berikut; (1) sebelah utara berbatasan dengan Selat Malaka; (2) sebelah selatan berbatasan dengan Kabupaten Aceh Besar; (3) sebelah Timur berbatasan dengan Kabupaten Aceh Besar dan (4) sebelah Barat berbatasan dengan Samudra Hindia. Berdasarkan letak geografis Kota Banda Aceh berada di ujung utara Pulau Sumatera sekaligus menjadi wilayah paling barat dari Pulau Sumatera (PUPR, 2018).

Kota Banda Aceh memiliki jumlah penduduk tahun 2017 sebanyak 259.913 orang yang terdiri dari 133.728 orang laki-laki dan 126.185 orang perempuan, jumlah penduduk tertinggi terdapat di Kecamatan Kuta Alam yaitu sebesar 52.130 jiwa dan jumlah penduduk terendah di Kecamatan Kuta Raja yaitu sebesar 13. 499 jiwa (BPS, 2018).

Berdasarkan Gambar 1, distribusi kasus penyakitDBD diKotaBandaAcehyaituKecamatan Jaya Baru dan Kecamatan Baiturrahman masingmasing terdapat 37 kasus, Kecamatan Kuta alam dan Lueng Bata terdapat 32 kasus, Kecamatan Syiah Kuala terdapat 26 kasus, Kecamatan Banda Raya terdapat 25 kasus, Kecamatan Ulee Kareng terdapat 21 kasus, Kecamatan Meuraxa terdapat 15 kasus dan Kecamatan Kuta Raja terdapat 11

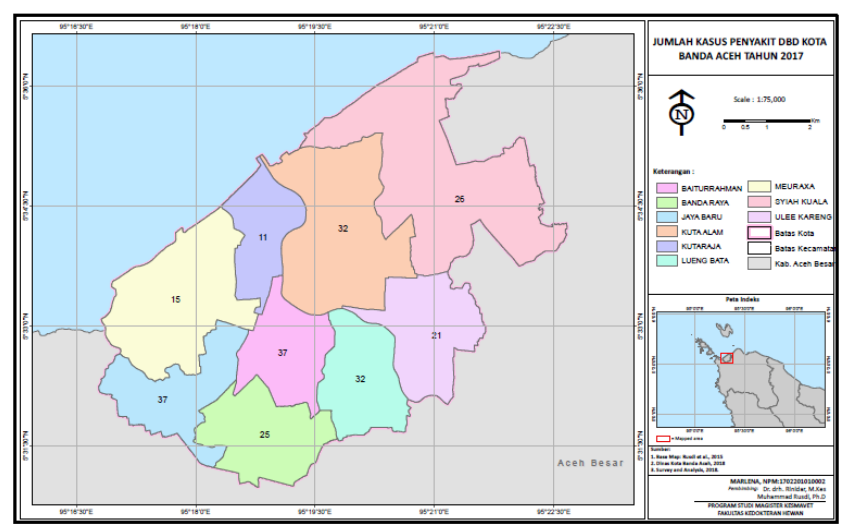

Gambar 1. Jumlah kasus penyakit DBD Kota Banda Aceh tahun 2017 
kasus. Distribusi kasus DBD katagori rendah terdapat sebanyak 39 desa. Dari 39 desa tersebut ada 9 desa yang merupakan desa dengan katagori pemukiman padat yaitu Desa Keudah, Keuramat, Laksana, Merduati, Neusu Jaya, Peunayong, Peuniti, Peurada dan Punge Jurong. Distribusi kasus DBD katagori sedang terdapat sebanyak 20 desa. Dari 20 desa tersebut ada 2 desa yang merupakan desa dengan katagori pemukiman padat yaitu Mulia dan Setui. Distribusi kasus DBD katagori tinggi terdapat sebanyak 15 desa. Ada 5 desa yang merupakan desa dengan katagori pemukiman padat yaitu Ateuk Pahmawan, Emperom, Lamteumen Timur, Panterik dan Sukaramai.

Tabel 2. Distribusi kepadatan permukiman berdasarkan luas pemukiman di Kota Banda Aceh

\begin{tabular}{cccc}
\hline $\begin{array}{c}\text { Kepadatan } \\
\text { permukiman }\end{array}$ & $\begin{array}{c}\text { Luas Pemukiman } \\
\text { (ha) }\end{array}$ & $\begin{array}{c}\text { Jumlah } \\
\text { (desa) }\end{array}$ & \% \\
\hline Jarang & $1-10$ & 42 & 46.7 \\
Sedang & $11-21$ & 31 & 34.4 \\
Padat & $22-32$ & 17 & 18.9 \\
\hline
\end{tabular}

Berdasarkan Tabel 2, desa yang memiliki kepadatan permukiman jarang sebanyak 42 desa atau $46.7 \%$, desa yang memiliki kepadatan permukiman sedang sebanyak 31 desa atau $34.4 \%$ dan desa yang memiliki kepadatan permukiman padat sebanyak 17 desa atau $18.9 \%$.

Berdasarkan Tabel 3 dapat diketahui bahwa desa yang memiliki jumlah kasus DBD sedikit dengan kepadatan permukiman jarang sebesar $31,1 \%$, desa yang memiliki jumlah kasus DBD sedikit dengan kepadatan permukiman sedang sebesar $21,1 \%$, desa yang memiliki jumlah kasus DBD sedikit dengan kepadatan permukiman padat sebesar $8,9 \%$, desa yang memiliki jumlah kasus
DBD sedang dengan kepadatan permukiman jarang sebesar $10,0 \%$, desa yang memiliki jumlah kasus DBD sedang dengan kepadatan permukiman sedang sebesar $6,7 \%$, desa yang memiliki jumlah kasus DBD tinggi dengan kepadatan permukiman jarang sebesar 5,6\%, desa yang memiliki jumlah kasus DBD tinggi dengan kepadatan permukiman sedang sebesar $6,7 \%$ dan desa yang memiliki jumlah kasus DBD tinggi dengan kepadatan permukiman tinggi sebesar $4,4 \%$.

Berdasarkan uji statistik Chi Square antara kepadatan permukiman dengan sebaran kasus DBD menunjukan kepadatan permukiman tidak mempengaruhi pola sebaran DBD di Kota Banda Aceh dengan nilai $\mathrm{P}>0,05$.

Pada Gambar 2 menjelaskan tingkat kepadatan permukiman terhadap sebaran kasus DBD kota Banda Aceh berdasarkan data kasus DBD tahun 2017. Daerah kepadatan permukiman jarang sebesar 46,7\% memiliki 3 titik kasus DBD katagori tinggi terdapat pada Kecamatan Lueng Bata yaitu Desa Batoh, Lamdom dan Blang Cut. Daerah kepadatan permukiman sedang sebesar 34,4\% memiliki 7 titik kasus DBD katagori tinggi terdapat pada kecamatan Ulee Kareng ada 2 desa

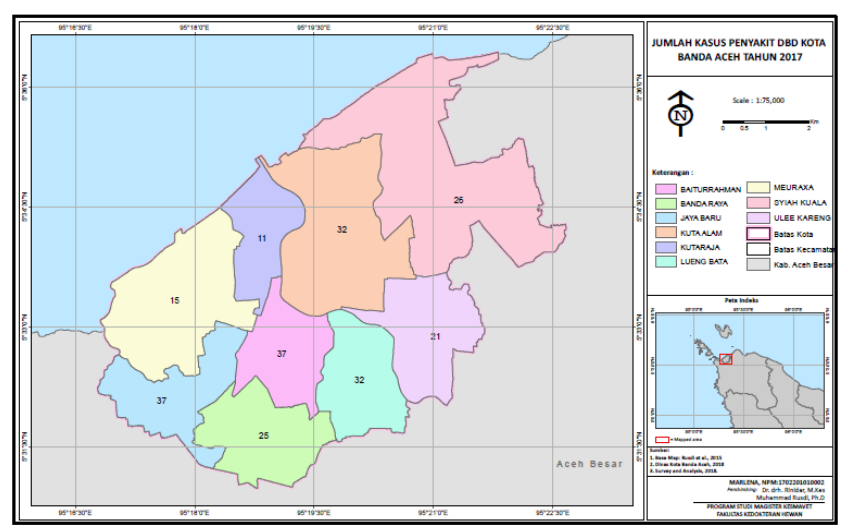

Gambar 2. Peta kepadatan permukiman dan sebaran DBD di Kota Banda Aceh

Tabel 3. Hubungan kejadian DBD dengan Kepadatan Permukiman di Kota Banda Aceh

\begin{tabular}{|c|c|c|c|c|c|c|c|c|}
\hline \multirow{3}{*}{ Jumlah Kasus } & \multicolumn{6}{|c|}{ Kepadatan Permukiman } & \multirow{3}{*}{$\begin{array}{l}\text { Jumlah } \\
\text { Volume }\end{array}$} & \multirow{3}{*}{$\%$} \\
\hline & \multicolumn{2}{|c|}{ Jarang } & \multicolumn{2}{|c|}{ Sedang } & \multicolumn{2}{|c|}{ Padat } & & \\
\hline & Vol & $\%$ & Vol & $\%$ & Vol & $\%$ & & \\
\hline Rendah & 28 & 31.1 & 19 & 21.1 & 8 & 8.9 & 55 & 61.1 \\
\hline Sedang & 9 & 10.0 & 6 & 6.7 & 5 & 5.6 & 20 & 22.2 \\
\hline Tinggi & 5 & 5.6 & 6 & 6.7 & 4 & 4.4 & 15 & 16.7 \\
\hline Jumlah & 42 & 46.7 & 31 & 34.4 & 17 & 18.9 & 90 & 100 \\
\hline
\end{tabular}


yaitu Desa Ceurih dan Ie Masen Kayee Adang, Kecamatan Syiah Kuala ada 1 desa yaitu Desa Pineueng, Kecamatan Banda Raya ada 1 desa yaitu Desa Geuceu Komplek, Kecamatan Kuta Alam ada 1 desa yaitu Desa Lampulo, Kecamatan ada 1 desa yaitu Neusu Aceh dan Kecamatan Jaya Baru ada 1 desa yaitu Desa Punge Blang Cut. Daerah kepadatan permukiman padat sebesar 18.9\% memiliki 5 titik kasus DBD katagori tinggi terdapat pada Kecamatan Jaya Baru ada 2 desa yaitu Desa Emperom dan Lamteumen Timur, Kecamatan Baiturrahman ada 2 desa yaitu Desa Ateuk pahlawan dan Sukaramai dan Kecamatan Lueng Bata ada 1 desa yaitu Desa Panterik.

Banda Aceh merupakan kota kecil dengan luas wilayah permukiman padat sebesar $18,9 \%$ dari jumlah wilayah kota Banda Aceh. Pada Gambar 2 menjelaskan tingkat kepadatan permukiman terhadap sebaran DBD kota Banda Aceh. Daerah berwarna merah menggambarkan daerah permukiman padat, daerah berwarna kuning menggambarkan daerah permukiman sedang dan daerah berwarna hijau menggambarkan daerah permukiman jarang. Pada daerah permukiman padat hanya terdapat 5 desa dari 90 desa yang ada di Kota Banda Aceh yang memiliki kasus DBD katagori tinggi yaitu Desa Emperom, Lamteumen Timur, Ateuk pahlawan, Sukaramai dan Panterik. Persentase daerah permukiman padat dengan kasus DBD katagori tinggi hanya sebesar 5,55\%. Hasil uji statistik menyatakan bahwa kepadatan permukiman di Kota Banda Aceh tidak mempengaruhi penyebaran kasus penyakit DBD. Hal ini tidak sesuai dengan penelitian (Indrayati dan Setyaningsih, 2013). yang menyatakan faktor kepadatan perumahan berhubungan dengan kasus DBD.

Selain kepadatan permukiman, faktor lainnya yang mempengaruhi kejadian DBD adalah kepadatan penduduk suatu daerah (Prasetyowati, 2015). Kepadatan penduduk yang tinggi dipusat-pusat perkotaan dengan perumahan dibawah standar, sarana air yang tidak memadai, saluran pembuangan dan limbah yang buruk menciptakan kondisi ideal untuk meningkatkan perkembangbiakan nyamuk Aedes. Aedes aegypti adalah nyamuk perkotaan yang hidup ditengah masyarakat dan berkembang biak dalam wadah buatan manusia (Gubler, 1997). Frekuensi nya- muk menggigit dipengaruhi oleh keberadaan manusia. Estimasi Aedes aegypti menggigit pada permukiman padat lebih tinggi dari frekuensi menggigit di permukiman yang kurang padat (Candra, 2010). Pusat-pusat perkotaan adalah tempat berkembang biak demam berdarah, virus dengue dengan ketahanan yang lebih baik diangkut ke kota-kota lain melalui orang yang terinfeksi bepergian dengan pesawat jet (Gubler, 2004).

Kepadatan penduduk berperan di mana wilayah padat penduduk bisa menjadi area berisiko tinggi untuk demam berdarah (Naqvi et al., 2015). Semakin tinggi kepadatan penduduk di suatu wilayah dapat menyebabkan kurangnya keseimbangan antara penduduk dan lingkungan sehingga dapat menyebabkan sanitasi lingkungan yang kurang baik dan penularan penyakit bertambah cepat (Kemkes, 2012). Kepadatan penduduk terkait juga dengan kebutuhan persediaan air bersih dimana semakin besar jumlah dan kepadatan penduduk, maka semakin banyak pula kebutuhan air (Anggraini et al., 2013). Adanya penderita DBD pada daerah padat akan meningkatkan peluang orang lain terkena penyakit DBD (Li et al., 2012).

Kepadatan penduduk kota Banda Aceh tahun 2017 adalah 4.236 jiwa setiap $1 \mathrm{~km}^{2}$. Dari sembilan kecamatan yang ada di Kota Banda Aceh, Kecamatan Baiturrahman memiliki kepadatan penduduk tertinggi yaitu 8.088 jiwa/ km2. Sedangkan Kecamatan Kuta Raja memiliki kepadatan penduduk terendah adalah 2.565 jiwa/km2. Daerah kepadatan permukiman padat yang memiliki kasus DBD katagori tinggi yaitu Desa Emperom memiliki luas wilayah 27,8 Ha, jumlah penduduk 2.790 jiwa dan jumlah rata-rata penduduk 100 jiwa per ha. Desa Lamteumen Timur memiliki luas wilayah 50,5 Ha, jumlah penduduk 5.577 jiwa dan jumlah rata-rata penduduk 110 jiwa per ha. Desa Ateuk pahlawan memiliki luas wilayah 49,85 Ha, jumlah penduduk 5.420 jiwa dan jumlah rata-rata penduduk 109 jiwa per ha. Desa Sukaramai memiliki luas wilayah sebesar 49,75 Ha, jumlah penduduk 4.491 jiwa dan jumlah rata-rata penduduk 90 jiwa per ha. Desa Panterik memiliki luas wilayah sebesar 51,3 Ha, jumlah penduduk 4.462 jiwa dan jumlah rata-rata penduduk 87 jiwa per ha (BPS, 2018). 
Beberapa penelitian menyatakan faktorfaktor lain yang berhubungan dengan kejadian DBD adalah mobilitas, urbanisasi, pertumbuhan penduduk, ekonomi, perilaku masyarakat, perubahan iklim, sanitasi lingkungan dan ketersediaan air bersih (Ali and Ma'rufi, 2016). Perubahan demografis dan sosial seperti transportasi modern berperan dalam peningkatan kejadian dan penyebaran virus dengue (Setiati et al., 2006).

Kejadian DBD akan meningkat di daerah dengan aktivitas manusia yang tinggi, seperti daerah perumahan, kawasan industri dan sekolah-sekolah (Gubler dan Meltzer, 1999). Daerah tersebut merupakan daerah yang banyak manusia melakukan kegiatan (Shafie, 2011). Selain tempat-tempat dengan aktivitas manusia yang tinggi, tempat-tempat yang ditinggalkan juga bisa menjadi tempat berkembangbiak bagi nyamuk. Pemakaman, yang memiliki wadah seperti vas bunga, dapat menjadi sumber untuk perkembangbiakan nyamuk Aedes (Chang et al., 2011).

Pasca tsunami tahun 2004, lahan yang ada di Kota Banda Aceh banyak dimanfaatkan untuk pembangunan perumahan. Bangunan-bangunan baru tersebut banyak yang berbentuk komplek yang saling berdekatan (Dinas PUPR, 2018). Pola sebaran penduduk dan perumahan yang saling berdekatan mempengaruhi proses penularan DBD (Indrayati dan Setyaningsih, 2013). Jarak terbang nyamuk kurang dari 40 meter dan mungkin lebih jika terbawa kendaraan atau angin sehingga penularan DBD terjadi pada radius 100 meter dari rumah penderita DBD (Anggraeni, 2010). Jarak penyebaran nyamuk Aedes aegypti tidak lebih dari 200 meter (Liu-Helmersson et al., 2014).

Banda Aceh memiliki pola permukiman yang berdekatan dengan aliran sungai, persawahan dan jalan lokal yang cenderung terjadi mobilitas penduduk yang cukup tinggi (Dinas PUPR, 2018). Banyaknya pepohonan rindang dan tempat penampungan air, sangat mendukung untuk tempat perindukan nyamuk. Pohon dan air tanah merupakan faktor penting dalam kejadian DBD (Ndenga et al., 2017). Pemukiman yang luas mempengaruhi kasus DBD di daerah perkotaan (Vanwambeke et al., 2006). Transmisi dengue sangat lokal dan dibatasi oleh ruang dan waktu (Ibarra, et al., 2014).
Perpindahan penduduk dari perdesaan ke perkotaan mempengaruhi pola persebaran dan kejadian DBD (Telle et al., 2016). Pertumbuhan penduduk yang tidak memiliki pola tertentu merupakan salah satu faktor yang berperan dalam munculnya DBD. Perkembangan perkotaan telah menyebabkan meningkatnya sumber daya air buatan, seperti tempat penyimpanan air, ban atau wadah lama di tempat sampah untuk diternakkan oleh vektor (Kumar et al., 2001). Kejadian DBD erat kaitannya dengan sumber penularan berupa tempat perindukan nyamuk penular dan status DBD itu sendiri yang merupakan penyakit menular yang disebabkan oleh gigitan vektor nyamuk Aedes aegypti yang didalam tubuhnya telah mengandung virus dengue (Cameron et al., 2012). Dengue yang ditularkan ke manusia oleh nyamuk Aedes aegypti perempuan dengan tingkat transmisi yang tinggi sepanjang hari dan malam di daerah perkotaan (Pereda et al., 2014).

\section{Kesimpulan}

Daerah kepadatan permukiman padat kota Banda Aceh memiliki kasus DBD kategori tinggi sebesar $18.9 \%$ dan hasil uji statistik memperlihatkan nilai $\mathrm{P}>0,05$, artinya tidak terdapat hubungan kepadatan permukiman dengan luas permukiman terhadap sebaran demam berdarah dengue (DBD) di Kota Banda Aceh.

\section{Ucapan Terima Kasih}

Penelitian ini didukung oleh Kementerian Kesehatan Republik Indonesia melalui Universitas Syiah Kuala (Beasiswa Pasca Sarjana).

\section{Daftar Pustaka}

Ali, K., and Ma'rufi, I. (2016). Study of Factors Caused Dengue Haemorrhagic Fever Case Study: Pasuruan, Jawa Timur Indonesia. Journal of Medical and Bioengineering (5): 108-112.

Anggraeni DN. (2010). Stop! demam berdarah dengue. Bogor: Bogor Publ House

Anggraini, F.D., Samadi., dan Warnadi. (2013). Pengaruh kebutuhan penduduk terhadap kebutuhan air bersih di Pulai Panggang, 
Provinsi DKI Jakarta. Spasial Wahana Komunikasi dan Informasi Geografi. 12 (2): 25-30.

Badan Pusat Statistik Kota Banda Aceh. (2018). Kota Banda Aceh dalam Angka 2018. Banda Aceh

Cameron, R.W.F., Blanusa, T., Taylor, J.E., Salisbury, A., Halstead, A.J., Henricot, B., and Thompson, K. (2012). The dosmetic garden its contribution to urban green infrastructure. Urban Foresty \& Urban Greening. 11(2): 129-137.

Candra, A. (2010). Demam berdarah dengue, epidemiologi, patogenesis, dan faktor risiko penularan. Aspirator. (2): $110-119$.

Chang, A.Y., Maria, E.P., Javier, Jimenez., Magdalena. E.S., Scott, M.H., David, J.C., and Rajan, P. K. (2009). Combining Google Earth and GIS mapping technologies in a dengue surveillance system for developing countries. International Journal of Health Geographics. 8:49

doi:10.1186/1476-072X-8-49.

Chang, M.S., Christophel, E.M., Gopinath, D., Abdur, R. (2011). Challenges and future perspective for dengue vector control in Western Pacific Region. West Pacific Surveill Response.(2): 9-16.

Dinas Cipta Karya PU. (2006). Konsep Pedoman Identifikasi Kawasan Permukiman Kumuh Penyangga Kota Metropolitan. Jakarta.

Dinas Kesehatan Kota Banda Aceh. (2017). Laporan kasus dan kematian deman berdarah dengue Kota Banda Aceh tahun 2016. Banda Aceh.

Dinas Kesehatan Kota Banda Aceh. (2018). Profil Dinas Kesehatan Kota Banda Aceh tahun 2017. Banda Aceh.

Dinas Pekerjaan Umum dan Penataan Ruang. (2018). Profil Dinas PUPR Kota Banda Aceh tahun 2017. Banda Aceh

Drobne, S., dan Lisec, A. (2009). Multi-attribute decision analysis in GIS: weighted linear combination and ordered weighted averaging. Informatica. : 459-474.
Gubler, D.J.(2004). Cities spawn epidemic dengue viruses. Nat Med; 10: 129-130

Gubler, D.J. (1997). Dengue and Dengue Hemorrhagic Fever: Its History and Resurgence as a Global Public Health Problem In: Gubler DJ, Kuno G, eds. Dengue and Dengue Hemorrhagic Fever. London: CAB International; pp. 1-22

Gubler, D.J and Meltzer, M. (1999). Impact of dengue/dengue hemorrhagic fever on the developing world. Adv Virus Res. (53): 3570 .

Hadinegoro, S.R.H., dan Satari, H.I. (2004). Demam Berdarah Dengue, Jakarta, Balai Penerbit Fakultas Kedokteran Universitas Indonesia, h. 17.

Ibarra, A.M.S., Luzadis, V.A., Cordova, M.J.B., Silva, M., Ordoñez, T., Ayala, E.B., and Ryan, S.J. (2014). A social-ecological analysis of community perceptions of dengue fever and Aedes aegypti in Machala, Ecuador. BMC Public Health. 14 (1135): 2-14.

Indrayati A dan Setyaningsih W. (2013). Penentuan lokasi priortas penanganan kasus demam berdarah di Kota Semarang berbasis sistem informasi geografis. Jurnal Forum Ilmu Sosial. (40): 56-67.

Kementerian Kesehatan. (2012). Data penyakit tahun 2011 yang menurun dibandingkan dengan 2010. Direktur Jenderal Pengendalian Penyakit dan Penyehatan Lingkungan. Jakarta.

Kementerian Kesehatan. (2018). Profil Kementerian Kesehatan Tahun 2017. Jakarta.

Koban, A.W. (2005). Kebijakan pemberantasan wabah penyakit menular: Kasus kejadian luar biasa demam berarah dengue (KLB DBD). The Indonesian Institute. Center For Public Policy Research. 1-35.

Kumar, A., Sharma, S., Padbidri, V., Thakare, J., Jain, D., and Datta, K. (2001). An outbreak of dengue fever in rural areas of northern India. Jounal Commun Dis. (33):274-81. 
Kurniadi, A. (2014). Analisis kualitas lingkungan permukiman di Kecamatan Kotagede Kota Yogyakarta menggunakan citra quickbird. Journal Universitas Negeri Yogyakarta. (3):1-9.

Li, Z., Yin, W., Clements, A., Williams, G., Lai, S., Zhou, H. (2012). Spatiotemporal analysis of indigenous and imported dengue fever cases in Guangdong province, China. BMC Infectious Diseases. (12): 132.

Liu-Helmersson, J., Stenlund, H., Wilder-Smith, A., and Rocklov, J. (2014). Vectorial capacity of Aedes aegypti: effects of temperature and implications for global dengue epidemic potential. PLoS ONE; 9:e89783.

Naqvi, SAA, Kazmi, SJH, Shaikh, S and Akram, M. (2015).Evaluation of prevalence Patterns of Dengue Fever in Lahore District through Geo-Spatial Techniques. Journal of Basic and Applied Sciences;11:20-30.

Ndenga, B.A., Mutuku, F.M., Ngugi, H.N., Mbakaya, J.O., Aswani, P., and Musunzaji, P.S. (2017). Characteristics of Aedes aegypti adult mosquitoes in rural and urban areas of western and coastal Kenya. PLoS ONE. (12): 1-14.

Pereda, P.C., Menezes, T.A., Alves, D. (2014) Impact of Climate Change on Dengue Risk in Brazil (Russia: European Regional Science Association).

Prasetyo. (2012). Analisis spasial penyebaran penyakit DBD di Kecamatan Magetan Kabupaten Magetan. Tesis. Program Pascasarjana Fakultas Kedokteran Universitas Gajah Mada Yogyakarta.

Prasetyowati, I. (2015). Kepadatan penduduk dan insidens rate demam berdarah dengue (Dbd) Kabupaten Bondowoso, Jawa Timur. Indonesia. Jurnal Heal Sci. 5(2).

Setiati, T.E., Wagenaar, J.F., Kruit, M.D., Mairuhu, A.T., Gorp, E.C., Soemantri, A. (2006). Changing epidemiology of dengue haemorrhagic fever in Indonesia. Dengue Bull. (30): 1-14.
Shafie, A. (2011). Evaluation of the spatial risk factors for high incidence of dengue fever and dengue hemorrhagic fever using GIS application. Sains Malaysiana. 40(8): 93743.

Sujariyakul, A., Prateepko, S., Chongsuvivatwong, V., Thammapalo, S. (2005). 'Transmission of Dengue Hemorrhagic Fever: At home of School?', Dengue Bulletin. (29): 32-40.

Sunaryo, Bina Ikawati, Dewi Puspita Ningsih. (2014). Distribusi spasial demam berdarah dengue di Kabupaten Banyumas, Provinsi Jawa Tengah. Balaba. 10(01): 1-8.

Telle, O., Vaguet, A, Yadav, N.K., Lefebvre, B., Daudé, E., Paul, R.E., et al. (2016). The spread of dengue in an endemic urban milieu-the case of Delhi, India. PLoS ONE 11(1): e0146539.

Vanwambeke, S.O., Benthem, B.H.B.V., Khantikul, N., Burghoorn-Maas, C., Panart, K., Oskam, L., Lambin, E.F., and Somboon, P. (2006). Multi-level analyses of spatial and temporal determinants for dengue infection. International Journal of Health Geographics. (5):1-16.

Widyawati, Nitya, I.F., Syaukat, S., Tambunan, R.P., dan Soesilo, T.E.B. (2011). Penggunaan sistem informasi geografi efektif memprediksi potensi demam berdarah di Kelurahan Endemis. Makara Kesehatan. (15): 21-30.

World Health Organization. (2009). Neglected Tropical Disease (Geneva: World Health Organization) p 32.

World Health Organization. (2012). Dengue and severe dengue. Mediacentre/factsheets/ fs112012WHO. 


\title{
Gambaran Leukosit Kucing Penderita Feline Panleukopenia
}

\section{Leucocyte Profiling in Cat With Feline Panleukopenia}

\section{Hary Purnamaningsih, Soedarmanto Indarjulianto*, Yanuartono, Alfarisa Nururrozi, Irkham Widiyono, Rusmihayati}

\author{
Departemen Ilmu Penyakit Dalam, Fakultas Kedokteran Hewan Universitas Gadjah Mada, Jl. Fauna No.2, \\ Karangmalang, Depok, Sleman. 55281 Yogyakarta, Indonesia \\ *Coresponding author, Email: indarjulianto@ugm.ac.id
}

Naskah diterima: 27 September 2019, direvisi: 27 Oktober 2019, disetujui: 30 Desember 2019

\begin{abstract}
One of the diseases in cats with high morbidity and mortality is feline panleucopenia (FPL). This study aims to evaluate the total leukocytes to determine the prognosis in cats suffer Feline Panleukopenia. This study used 27 male and female cats of various ages, that have been diagnosed as FPL based on the feline parvo virus $\mathrm{Ag}$ test. As much as $1 \mathrm{ml}$ blood sample were collected from all of cats to examinated the total of leukocytes, then analyzed descriptively. The results showed that a total of 19 FPL $(70.4 \%)$ had a total of leukocytes $<1,000$ cells/ $\mathrm{mm}^{3}$, 4 FPL (14.8\%) $1,000-2,500$ cells $/ \mathrm{mm}^{3}$ and 4 others $(14.8 \%)>2,500$ cells $/ \mathrm{mm}^{3}$. The incidence of FPL was more in cats $\leq 6$ months, ie $21(77,8 \%)$ compared to $>6$ months, ie 6 cats $(22,2 \%)$. Feline Panleukopenia was suffered by more male $(59.3 \%)$ than females $(40.7 \%)$ cats. Based on the results of this study it was concluded that the majority of feline panleukopenia have very low leukocytes with infausta prognosis, especially in male and young cats.
\end{abstract}

Key words: cat; Feline Panleukopenia; leukocyte

\begin{abstract}
Abstrak
Salah satu penyakit pada kucing dengan morbiditas dan mortalitas tinggi adalah Feline Panleukopenia (FPL). Tujuan dari penelitian ini adalah mengetahui jumlah leukosit untuk menentukan prognosis pada kucing jantan dan betina berbagai umur penderita Feline Panleukopenia. Penelitian ini menggunakan 27 ekor kucing jantan dan betina berbagai umur yang didiagnosa FPL berdasar Feline Parvo Virus Ag test. Semua kucing diambil darah secara lege artis sebanyak $1 \mathrm{ml}$, diperiksa jumlah leukositnya, kemudian dianalisis secara diskriptif. Hasil penelitian menunjukkan bahwa sebanyak 19 ekor (70,4 \%) FPL mempunyai jumlah total leukosit $<1.000$ sel/ $\mathrm{mm}^{3}$, 4 ekor (14,8 \%) $1.000-2.500 \mathrm{sel} / \mathrm{mm}^{3}$ dan 4 ekor yang lain $(14,8 \%)>2.500 \mathrm{sel} / \mathrm{mm}^{3}$. Kejadian FPL lebih banyak diderita kucing umur $\leq 6$ bulan, yaitu 21 ekor (77,8\%) dibanding umur $>6$ bulan, yaitu 6 ekor (22,2\%). Feline Panleukopenia lebih banyak diderita kucing jantan (59,3 \%) dari pada betina (40,7\%). Berdasarkan hasil penelitian ini disimpulkan bahwa sebagian besar penderita Feline Panleukopenia mengalami penurunan leukosit berat dengan prognosis infausta, terutama pada kucing jantan dan umur muda.
\end{abstract}

Kata kunci: Feline Panleukopenia; kucing; leukosit 